\title{
Cara Sukses Menyusun Nama untuk Bisnis Start-up
}

\author{
Richard Devlin Tanujaya Halim \\ Program Studi Kewirausahaan \\ Universitas Bina Nusantara \\ richard.halim@binus.ac.id
}

Keberadaan wirausaha di Indonesia sebanyak 9,4 juta jiwa diharapkan dapat terus meningkat seiring dengan banyaknya pengusaha muda yang mulai menjalankan bisnisnya. Target nasional sebesar 10,8 juta wirausaha di tahun 2024 (Safitri, 2021). Hal ini menyebabkan semakin sulitnya dalam memilih nama bisnis yang belum terdaftarkan, unik, dan sesuai dengan identitas merek yang ingin dibangun oleh wirausaha. Bagaimana caranya menyusun nama untuk ide bisnis kita?. Nama bisnis yang sesuai dan dapat mendukung perkembangan merek dengan baik.

\section{Menentukan jenis nama bisnis yang diinginkan}

Branding Consultant, Jonathan Bell menjelaskan terdapat 7 jenis kategori nama bisnis yang dapat kita pilih (Bell, 2020).

a. Kategori nama bisnis eponim

Nama-nama bisnis eponim tersusun menggunakan nama pendiri atau nama keluarga pendiri. Nama bisnis seperti Toyota, Mitsubishi, House of Raminten, Sambal Bu Rudy, dan Wardaya College termasuk dalam kategori ini. Namun bisnis yang tersusun dari nama nama karakter dan tokoh penting yang tidak secara langsung mendirikan bisnis juga dapat dikategorikan dalam nama bisnis Eponim, seperti Starbucks, dan Tesla Motors. b. Kategori nama bisnis deskriptif

Nama bisnis deskriptif menjelaskan sekilas soal value proposition yang ditawarkan dalam nama bisnisnya. Nama bisnis seperti Pos Indonesia, Kereta Api Indonesia, Kopi Kapal Api, dan Kecap Bango tergolong dalam kategori ini. Nama bisnis Deskriptif dapat terkesan panjang, generik, dan sulit untuk didaftarkan sebagai nama merek. Namun dengan nama deskriptif, konsumen dapat secara sekila memahami apa yang ditawarkan oleh bisnis tersebut.

c. Kategori nama bisnis akronim

Nama bisnis akronim merupakan nama bisnis yang berupa singkatan dari nama sepenuhnya. Nama bisnis seperti BCA, BNI, BRI, ABC, dan Pertamina merupakan bentuk akronim dari nama bisnis lengkap mereka. Nama bisnis akronim dapat digunakan untuk mempersingkat dan mempermudah penutur bahasa asing untuk membacanya.

d. Kategori nama bisnis sugestif 
Nama bisnis sugestif menjelaskan sekilas soal bisnis nya, namun tidak secara langsung layaknya nama bisnis deskriptif. Nama bisnis sugestif dapat disusun menggunakan modifikasi dan penggabungan antara kata-kata yang dapat ditemukan di dalam kamus. Nama bisnis seperti Indomie, Mie sedap, Youtube, Facebook, Bukalapak, Tolak Angin, Indomaret, Tokopedia, Indofood, dan Alfamart sekilas menjelaskan soal value proposition yang ditawarkan bisnis, namun secara implisit.

e. Kategori nama bisnis asosiatif

Nama bisnis asosiatif tersusun dengan modifikasi kata kata umum dalam berbagai bahasa yang memiliki arti yang ingin diasosiasikan dengan bisnis tersebut. Nama bisnis seperti Pampers, Red Bull, Omega, Garuda Indonesia, Eiger, dan Grab dipilih karena katakata ini memiliki asosiasi yang baik dan dapat merepresentasikan sekilas soal bisnis mereka.

f. Kategori nama bisnis non-Bahasa Indonesia, dan non Bahasa Inggris

Nama bisnis ini disusun dengan memodifikasi kata-kata yang memiliki arti dalam bahasa bahasa tertentu. Nama bisnis seperti Audi, Zappos, Samsung, dan Xiaomi merupakan nama-nama yang tersusun dengan kata-kata dalam berbagai bahasa selain Bahasa Indonesia dan Bahasa Inggris.

e. Kategori nama bisnis abstrak

Nama bisnis Abstrak tidak tersusun dengan kata-kata yang memiliki arti tertentu, namun disusun dengan tujuan untuk terdengar baik dan mudah diucapkan oleh berbagai penutur bahasa. Bisnis dengan nama bisnis Abstrak lebih bebas dalam menentukan apa arti dan maksud dari nama usahanya. Nama bisnis seperti Gojek, Kodak, dan Erigo termasuk dalam bisnis dengan nama Abstrak. Dalam menentukan jenis nama bisnis, kita dapat memilih beberapa jenis yang nantinya akan dieksplorasi (Finkle, 2019).

\section{Menentukan pesan tersirat yang ingin disampaikan kepada konsumen melalui nama bisnis}

Berdasarkan tujuh jenis nama bisnis Jonathan Bell, terdapat banyak sekali jenis kombinasi pesan yang dapat kita sampaikan secara tersirat terhadap konsumen. Walaupun terdapat banyak nama bisnis yang menggunakan nama pendiri atau nama keluarga, nama bisnis yang baik dapat menyampaikan pesan yang lebih mendalam. Nama-nama bisnis tidak hanya perlu mendeskripsikan, tetapi perlu menyampaikan suatu ide, gagasan, dan suatu harapan yang dapat mengajak audiens untuk merasakan sesuatu. Nama bisnis yang baik dapat menyentuh konsumen dari sisi emosional juga. Karena hubungan baik antara produsen dan konsumen dimulai dari nama bisnis yang baik.

Bila melihat lebih dalam nama bisnis "Go-pro" , mengandung nilai emosional dalam sisi mengajak konsumen untuk "go pro" atau menjadi lebih profesional dalam 
hal pembuatan konten video dan foto bersama kamera dan gadget Go-pro. Tokopedia juga menarik dengan kombinasi kata "Toko" dan "Ensiklopedia" yang menggambarkan kepraktisan Tokopedia untuk konsumen sebagai toko dimana berbagai hal mulai dari A-Z dapat ditemukan untuk dibeli. Nilai-nilai yang memiliki pesan emosional dalam nama bisnis dapat menarik hati calon konsumen, membuat mereka merasakan sesuatu dan mengajak mereka untuk melihat bisnis kita, dan menikmati produk dan jasa yang kita tawarkan (Harroch, 2016).

\section{Mengecek nama bisnis pilihan anda}

Pengecekan nama bisnis pilihan dapat dilakukan dari berbagai sudut pandang, pengecekan-pengecekan ini dilakukan agar nama bisnis yang sudah dipilih memang benar-benar sesuai dengan apa yang diinginkan oleh bisnis kita. Berikut apa saja yang perlu di cek dalam nama bisnis.

a. Penelusuran arti kata dalam bahasa-bahasa lain

Pengecekan ini dapat dilakukan melalui Machine Translation atau dengan konsultasi dengan translator. Apakah kata nama bisnis ini memiliki arti kurang baik? Apakah nama bisnis ini memiliki kesan kurang baik yang tidak sesuai dengan brand yang ingin dibangun? Pertanyaan seperti ini perlu ditelusuri dengan nama bisnis yang nantinya akan kita pilih. Sangat berbahaya pastinya, bila nantinya kita melakukan ekspansi ke negara lain dimana nama bisnis kita tidak diterima karena memiliki konotasi negatif di bahasa asing yang digunakan disana.

Upaya pemilihan nama dalam Bahasa Inggris juga perlu sangat diperhatikan, pastikan sudah berkonsultasi dengan ahli bahasa untuk arti kata yang nantinya akan diangkat menjadi nama bisnis.

b. Pengecekan cara pengucapan

Nama bisnis yang baik dapat diucapkan dan diingat dengan mudah oleh target pasarnya dan masyarakat luas. Bisnis di Indonesia banyak menggunakan kata kata sederhana yang dapat diucapkan mulai dari anak kecil hingga orang dewasa. Penutur Bahasa Indonesia juga unik, karena terkenal dapat mengucapkan kata kata dari berbagai bahasa asing dengan baik, namun kita juga tetap hati-hati. Kata-kata tertentu dalam bahasa asing mungkin terlalu sulit untuk dihafalkan oleh beberapa kalangan masyarakat dengan dialek lokal dan bahasa daerahnya.

c. Pengecekan di daftar perusahaan yang sudah terdaftar

Nama yang kita gunakan sebaiknya tidak sudah didaftarkan oleh perusahaan lain terlebih dahulu. Sebagai start-up, persiapan ini akan menghemat waktu dan dana seiring perusahaan berkembang. Kita dapat melakukan pengecekan nama yang terdaftar melalui 
berbagai situs web seperti web milik Kementerian Perindustrian (Kementerian Perindustrian, 2021), dan banyak situs web spesifik lainya untuk ketersediaan nama CV, seperti pengecekan melalui situs web Izin Kilat id (Izin Kilat, 2021).

Mengecek ketersediaan nama domain situs web juga diperlukan. Bisnis start-up masa kini perlu memiliki keberadaan di platform digital dan internet. Karena itu, mengecek ketersediaan nama domain sangat diperlukan. Pengecekan ini dapat dilakukan melalui vendor domain pilihan seperti situs web Godaddy (GoDaddy Operating Company, 2021), dan dari vendor-vendor dalam negeri seperti Niagahoster (Niagahoster, 2021), dan Domainesia.

Kita dapat secara kreatif memilih domain yang berbeda bilamana domain yang kita cari belum tersedia ataupun dijual dengan harga mahal. Tetapi, nama bisnis tersebut tetap merepresentasikan bisnis kita dengan baik. Seperti dalam kasus perusahaan Alphabet, domain Alphabet.com sudah dimiliki perusahaan BMW, jadi Alphabet menggunakan domain abc.xyz. Pemilihan domain yang kreatif, mudah diingat, dan sesuai dengan nama bisnis.

Menemukan nama yang sesuai dengan identitas merek yang ingin dibangun, mudah dihafalkan, dan tersedia untuk didaftarkan tidaklah mudah. Dengan target nasional sebesar 4 juta pengusaha Indonesia dimasa yang akan datang, memilih nama usaha yang unik menjadi semakin sulit. Namun hal ini tidak bisa menjadi demotivator calon pengusaha muda. Karena tidak apa-apa bila kita memerlukan waktu lebih untuk mencari beberapa nama lain hingga nantinya fokus ke 1 nama yang benar-benar sesuai. Karena usaha dalam pemilihan nama ini di awal, akan mendukung perkembangan usaha kita di kemudian hari (Barringer, 2015; Purnomo et al., 2020).

\section{References}

Barringer, B.R. (2015). Preparing Effective Business Plans: An Entrepreneurial Approach (2nd ed.). Pearson Education Limited.

Bell, J. (2020). How to create a great brand name by Jonathan Bell. Achiever Network Achnet. https://www.achnet.com/content/how-to-create-a-great-brand-namejonathan-bell

Finkle, C. (2019). Where do business names come from? The 7 types. - BMB. BMB. https://brandmarketingblog.com/articles/branding-definitions/7-types-of-names/

GoDaddy. (2021). Domain. GoDaddy Operating Company https://sg.godaddy.com/ 
Harroch, R. (2016). 12 Tips for Naming Your Startup Business. Forbes. https://www.forbes.com/sites/allbusiness/2016/10/23/12-tips-for-naming-yourstartup-business/?sh=1564a4e2904e

Izin Kilat. (2021). Izin. Izinkilat.id https://izinkilat.id/

Kementerian Perindustrian. (2021). Bisnis. Kementerian Perindustrian Republik Indonesia. https://kemenperin.go.id/

Niagahoster. (2021). Domain. Niaga Hoster. https://www.niagahoster.co.id/

Purnomo, A., Sudirman, A., Hasibuan, A., Sudarso, A., Sahir, S. H., Salmiah, Mastuti, R., Chamidah, D., Koryati, T., \& Simarmata, J. (2020). Dasar-Dasar Kewirausahaan: untuk Perguruan Tinggi dan Dunia Bisnis. Yayasan Kita Menulis. https://kitamenulis.id/2020/04/06/dasar-dasar-kewirausahaan-untuk-perguruantingi-dan-dunia-bisnis/

Safitri, K. (2021). Government Targets Indonesian Entrepreneurship Ratio of 4 Percent. Kompas.com.

https://money.kompas.com/read/2021/05/03/091000626/pemerintah-targetkanrasio-kewirausahaan-indonesia-4-persen

\section{Biografi}

\section{Richard Devlin Tanujaya Halim}

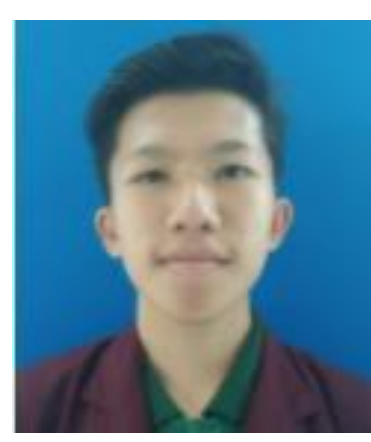

Penulis kelahiran Blitar ini adalah seorang mahasiswa program studi kewirausahaan di Universitas Bina Nusantara, kampus Malang sejak tahun 2020. Sembari mengikuti kegiatan lomba dan workshop, Richard sedang menjalankan rintisan wirausaha Foodline yang bergerak di bidang catering bekal untuk siswa. Penggemar mempelajari bahasa asing dan bisnis ini memiliki prinsip hidup bahwa "Kegagalan adalah keberhasilan yang tertunda" .

Email: richard.halim@binus.ac.id Instagram: @richard_halimn 